\title{
PENYELESAIAN SENGKETA LINGKUNGAN HIDUP DI LUAR PENGADILAN
}

\author{
Salmudin \\ (Dosen STIH Serasan Muara Enim) \\ Email: salmudin68@yahoo.com
}

\begin{abstract}
Sustainable development always causes changes to the environment, which causes damage. In order to resolve problems with those who have polluted the environment, it is done through the courts (Litigation) and through out of court (Non Litigation), while the settlement through the courts, can be done through the means of criminal law, civil law and administrative law. The problem in this article itself is First, how is the settlement of environmental disputes outside the court in civil law matters? Second, what are the obstacles in resolving environmental disputes outside the court? This article uses a normative approach to further analyze data qualitatively. Out-of-Court Dispute Settlement is actually held to reach agreement on the form and the amount of compensation, and / or certain actions, to ensure there is no occurrence or recurrence of negative impacts on the environment. The obstacles that are often faced by the settlement of environmental disputes outside the court are mainly related to the nominal and the form of compensation due to differences in views between pollutants and prosecutors. Another obstacle is the difficulty of administrative law enforcement in the context of environmental management, when faced with administrative decisions in the form of revocation of business licenses that will have a sociological economic impact causing pressure from the community / Non-Governmental Organizations (NGOs) to submit cases of pollution and damage to court hearings.
\end{abstract}

\section{Keywords: Environment, Dispute Resolution outside court}

Abstrak : Pembangunan berkelanjutan selalu menyebabkan perubahan terhadap lingkungan, yang menyebabkan kerusakan. Guna menyelesaikan permasalahanpermasalahan terhadap pihak yang telah melakukan pencemaran lingkungan hidup tersebut, dilakukan melalui jalur pengadilan (Litigasi) dan melalui jalur diluar pengadilan (Non Litigasi), sedangkan penyelesaian melalui jalur pengadilan, dapat dilakukan melalui sarana hukum Pidana, hukum Perdata dan hukum administrasi. Permasalahan dalam artikel ini sendiri adalah Pertama ,bagaimanakah penyelesaian sengketa lingkungan diluar pengadilan dalam masalah hukum perdata? Kedua, bagaimanakah hambatan dalam penyelesaian sengketa lingkungan di luar pengadilan?. Artikel ini mengunakan pendekatan normatif untuk selanjutnya menganalisis data secara kualitatif. Penyelesaian Sengketa di Luar Pengadilan sejatinya diselenggarakan untuk mencapai kesepakatan bentuk dan besarnya ganti rugi, dan/atau Tindakan tertentu, guna menjamin tidak terjadinya atau terulangnya dampak negatif terhadap lingkungan hidup. Hambatan yang kerap dihadapi penyelesaian sengketa lingkungan di luar pengadilan terutama menyangkut nominal dan bentuk ganti rugi akibat perbedaan pandangan antara pencemar dan penuntut. Hambatan lainnya adalah sulitnya penegakan hukum administratif dalam rangka pengelolaan lingkungan, apabila dihadapkan dengan keputusan administratif berupa pencabutan izin usaha yang akan berdampak secara sosiologis ekonomis 
menimbulkan desakan dari masyarakat/Lembaga Swadaya Masyarakat (LSM) untuk mengajukan kasus pencemaran dan perusakan ke sidang pengadilan

Keywords : Lingkungan Hidup, Penyelesaian Sengketa di luar pengadilan

\section{A. Latar Belakang}

Lingkungan hidup Indonesia yang dikaruniakan oleh Tuhan Yang Maha Esa kepada Bangsa dan Rakyat Indonesia, merupakan rahmat dari padaNya dan wajib dikembangkan dan dilestarikan kemampuannya agar dapat menjadi sumber dan penunjang hidup bagi Bangsa dan Rakyat Indonesia serta makhluk lainnya, demi kelangsungan dan peningkatan kualitas hidup itu sendiri.

Dua hal yang paling essensial dalam kaitannya dengan masalah pengelolaan lingkungan hidup, adalah timbulnya pencemaran dan perusakan lingkungan hidup. Masalah lingkungan hidup dewasa ini timbul karena kecerobohan manusia dalam pengelolaan lingkungan hidup. Masalah hukum lingkungan dalam periode beberapa dekade akhir-akhir ini menduduki tempat perhatian dan sumber pengkajian yang tidak ada habis-habisnya, baik ditingkat regional, nasional maupun internasional, karena dapat dikatakan sebagai kekuatan yang mendesak untuk mengatur kehidupan umat manusia dalam kaitannya dengan kebutuhan sumber daya alam, dengan tetap menjaga kelanjutan dan kelestarian itu sendiri. ${ }^{1}$

Secara yuridis formal kebijaksanaan umum tentang lingkungan hidup di Indonesia telah di tuangkan dalam Undang-Undang No. 4 Tahun 1982 Tentang Ketentuan Pokok Lingkungan Hidup, yang sejak tanggal 19 September 1997 telah diundangkan sebelum digantikan dengan Undang-Undang No.23 Tahun 1997 Tentang Pengelolaan Lingkungan Hidup. Pada perkembanganny akemudian lahirlah Undang-Undang Nomor 32 Tahun 2009 Tentang Perlindungan dan Pengelolaan Lingkungan Hidup. yang merupakan ketentuan payung terhadap semua bentuk peraturan-peraturan mengenai masalah di bidang lingkungan hidup.

Banyak prinsip ataupun azas yang terkandung dalam Undang-Undang Pengelolaan Lingkungan Hidup tersebut, sangat baik untuk tujuan perlindungan

1Nurd'a dan Sudharsono, Aspek Hukum, (Semarang: SatyaWacana, 1991), hlm.7. 
terhadap lingkungan hidup beserta segenap isinya. Namun demikian untuk penerapannya masih perlu di tindak lanjuti dengan berbagai peraturan pelaksana agar dapat beroperasi sebagaimana yang diharapkan.

Pengertian pencemaran dan perusakan lingkungan hidup tersebut di atas dapat kita jumpai dalam Pasal 1 angka 14 dan angka 16 Undang-Undang Perlindungan dan Pengelolaan Lingkungan Hidup Nomor 32 Tahun 2009, dimana pencemaran lingkungan hidup adalah masuknya atau dimasukkannya makhluk hidup, zat, energi dan atau komponen lain ke dalam lingkungan hidup oleh kegiatan manusia sehingga melampaui baku mutu lingkungan hidup yang telah ditetapkan.

Sedangkan perusakan lingkungan hidup adalah tindakan orang yang menimbulkan perubahan langsung atau tidak langsung terhadap sifat fisik, kimia dan atau hayatinya lingkungan hidup sehingga melampaui kriteria baku kerusakan lingkungan hidup. Pembangunan selalu menyebabkan perubahan terhadap lingkungan. Sebagian dari perubahan tersebut disebabkan tingkat pertambahan penduduk yang cukup besar dan ketersediaan sumber daya yang terbatas, oleh karena itu pendayagunaan sumber daya alam menjadi meningkat sesuai tingginya tingkat kebutuhan, hal ini cenderung menye babkan kegiatan pembangunan selalu mengalami perubahan yang bukan skala kecil lagi, baik menyangkut luas kegiatan maupun intensitasnya. Dengan kenyataan seperti ini dapat dikatakan permasalahan lingkungan yang terjadi lebih banyak timbul karena dampak sampingan dari suatu pembangunan. ${ }^{2}$

Adapun masalah lingkungan sendiri pada hakikatnya dapat di definisikan secara mendasar sebagai "perubahan dalam lingkungan hidup secara langsung maupun tidak langsung yang dapat menyebabkan akibat negatif terhadap kesehatan dan kesejahteraan manusia". Lingkungan yang tercemar secara langsung atau tidak langsung lambat laun, cepat atau lambat akan mengakibatkan kerusakan lingkungan, perusakan lingkungan apabila ditinjau dari peristiwa terjadinya dapat di bagi menjadi dua yakni kerusakan yang terjadi dengan sendirinya, yang disebabkan oleh: alam dan perbuatan manusia dan hlm. 15.

${ }^{2}$ Abdurrahman, Pengantar Hukum Lingkungan Indonesia, (Bandung: Alumni, 1998), 
kerusakan yang disebabkan pencemaran, baik yang berasal dari air, udara maupun tanah. ${ }^{3}$

Dengan demikian hal yang seperti ini tentunya akan membawa akibat kerugian kepada masyarakat setempat. Guna menyelesaikan permasalahanpermasalahan pencemaran lingkungan hidup tersebut dilakukan melalui jalur hukum yang telah ditentukan dengan sebaik mungkin dalam Peraturan Perundang-undangan yang telah ada. Hal tersebut di tempuh agar tidak terjadi kesewenang-wenangan bagi semua pihak, baik yang diduga sebagai pencemar atau pihak yang menderita akibat pencemaran tersebut. Di dalam praktek penyelesaian sengketa pencemaran lingkungan yang dapat merusak lingkungan hidup, ditempuh melalui jalur pengadilan (Litigasi) dan melalui jalur diluar pengadilan (Non Litigasi), sedangkan penyelesaian melalui jalur pengadilan, dapat dilakukan melalui sarana Hukum Pidana, Hukum Perdata dan Hukum Administrasi.

Sementara penyelesaian diluar pengadilan, dapat dilakukan secara musyawarah atau mediasi. Namun dalam proses pembuktiannya dalam penyelesaian masalah pencemaran lingkungan ini nampaknya masih menghadapi berbagai kendala yang cukup rumit. Pada kasus pencemaran kebanyakan penderita atau penggugat tidak memahami tingkah laku teknologi modern sementara disisi lain tergugat sangat menguasai informasi dan tingkah laku teknologi modern.

\section{B. Permasalahan}

Permasalahan yang diangkat dalam artikel ini adalah :

1. Bagaimanakah penyelesaian sengketa lingkungan diluar pengadilan dalam masalah hukum perdata?

2. Bagaimanakah hambatan dalam penyelesaian sengketa lingkungan di luar pengadilan?

${ }^{3}$ Subagyo, Hukum Lingkungan (Jakarta: Rineka Cipta, 2008), hlm. 23 


\section{Metode}

Penulisan artikel ini menggunakan pendekatan normatif dalam menganalisis berbagai peraturan perundang-undangan serta literatur yang terkait dengan perkembangan hukum lingkungan hidup dan penyelesaian sengketa lingkungan hidup terutama melalui jalur diluar pengadilan. Proses analisis data dilakukan secara kualitatif.

\section{Pembahasan}

Lingkungan Hidup dalam Pengertian Ekologi tidak mengenal batas wilayah, baik wilayah negara maupun administratif. Akan tetapi, lingkungan hidup yang berkaiatan dengan pengelolaan harus jelas batas wilayah wewenang pengelolaanya. Secara Hukum, lingkungan hidup Indonesia meliputi ruang tempat Negara Republik Indonesia melaksanakan hak kedaulatan dan hak berdaulat di dalam yurisdiksinya. Lingkungan hidup Indonesia memiliki nilai yang berharga sebagai tempat rakyat dan bangsa Indonesia menyelenggarakan kehidupan bermasyarakat, berbangsa, dan bernegara dalam segala aspeknya.

Lingkungan Hidup sebagai suatu Ekosistem terdiri atas berbagai subsistem, yang mempunyai Aspek sosial, Budaya, Ekonomi dan Geografi dengan corak ragam yang berbeda yang mengakibatkan daya dukung dan daya tampung lingkungan hidup yang berlainan. Keadaan yang demikian memerlukan pembinaan dan pengembangan yang didasarkan pada keadaan daya dukung dan daya tampung lingkungan hidup akan meningkatkan keselarasan, keserasian, dan keseimbangan subsistem yang berarti juga meningkatakan ketahanan subsistem itu sendiri. Pembinaan dan pengembangan subsistem akan mempengaruhi subsistem yang lain, yang pada akhirnya akan

mempengaruhi ketahanan ekosistem secara keseluruhan. Oleh karena itu pengelolaan lingkungan hidup menuntut dikembangkannya suatu sistem dengan keterpaduan sebagai ciri utamanya. Diperlukan suatu kebijaksanaan nasional pengololaan lingkungan hidup yang harus dilaksanakan secara taat atas dan konsekuen dari pusat sampai ke daerah.

Kegiatan Pembangunan yang makin meningkat mengandung resiko pencemaran dan perusakan lingkungan hidup sehingga struktur dan fungsi 
dasar ekosistem yang menjadi penunjang kehidupan dapat rusak. Pencemaran dan perusakan lingkungan hidup akan merupakan beban sosial, yang pada akhirnnya masyarakat dan pemerintah harus menanggung biaya pemulihannya. Pencemaran lingkungan hidup adalah masuknya atau dimasukkanya mahluk hidup , zat, energi dan atau komponen lain kedalam lingkungan hidup atau kegiatan manusia sehingga kualitasnya turun sampai ke tingkat tertentu yang menyebabkan Lingkungan hidup tidak dapat berfungsi sesuai dengan peruntukannya. ${ }^{4}$

Sedangkan pengertian dari perusakan lingkungan hidup adalah tindakan yang menimbulkan perubahan langsung atau tidak langsung terhadap sifat fisik dan atau hayatinya yang mengakibatkan lingkungan hidup tidak berfungsi lagi dalam menunjang pembangunan berkelanjutan. Pengelolaan lingkungan hidup yang diselengarakan dengan azas tanggung jawab negara, azas berkelanjutan, dan azas manfaat yang bertujuan untuk mewujudkan pembangunan yang berkelanjutan yang berwawasan lingkungan hidup dalam rangka pembangunan manusia Indonesia yang seutuhnya dan pembangunan masyarakat Indonesia seluruhnya yang beriman dan bertakwa kepada Tuhan Yang Maha Esa. ${ }^{5}$

Pengertian dan sumber Pencemaran Perairan Sesuai dengan UndangUndang Nomor 32 Tahun 2009 tentang Perlindungan dan Pengelolaan Lingkungan Hidup mengartikan bahwa pencemaran lingkungan adalah masuk atau dimasukannya makhluk hidup, zat, energi dan/atau komponen lain ke lingkungan hidup oleh kegiatan manusia sehingga melampaui baku mutu lingkungan hidup yang telah ditetapkan. ${ }^{6}$

Definisi yang panjang ini sendiri sesungguhnya dapat disederhanakan dengan melihat adanya tiga unsur dalam masalah pencemaran yaitu sumber perubahan akibat kegiatan manusia atau proses alam, bentuk perubahannya adalah berubahnya konsentrasi suatu bahan dalam lingkungan dan merosotnya fungsi lingkungan untuk menunjang kehidupan. Merosotnya kualitas lingkungan juga tidak akan menjadi perhatian besar jika

${ }^{4}$ Kementerian Lingkungan Hidup, Tentang Peraturan Perundang-Undangan (Jakarta: Cipata, 1997), hlm. 3

5Ibid

${ }_{6}^{6}$ Pasal 1, Undang-Undang Nomor 32 Tahun 2009. 
tidak terkait dengan kebutuhan hidup manusia sendiri sehingga bahasan tentang pencemaran dan konsep penanggulangannya lebih mengarah kepada upaya mengenai bentuk kegiatan manusia yang menjadi sumber pencemaran.

Sumber pencemaran air pada umumnya diakibatkan oleh kegiatan manusia. Besar kecilnya pencemaran akan tergantung dari jumlah dan kualitas limbah yang dibuang kesungai, baik limbah padat maupun cair.Berdasarkan jenis kegiatannya maka sumber pencemaran air dibedakan menjadi :

a. pengolahan industri adalah pencurahan limbah cair yang masuk kedalam air bersumber dari pembuangan sisa produksi, lahan pertanian, peternakan dan kegiatan domestik.

b. Sumber domestik/buangan rumah tangga adalah buangan yang berasal bukan dari industri melainkan berasal dari rumah tangga, kantor, hotel, restoran, tempat ibadah, tempat hiburan, pasar, pertokoan dan rumah sakit. ${ }^{7}$

\section{Penyelesaian Sengketa Lingkungan diluar Pengadilan Dalam Masalah Hukum Perdata}

Sengketa lingkungan hidup adalah perselisihan antara dua pihak atau lebih yang ditimbulkan adanya atau diduga adanya pencemaran dan atau perusakan lingkungan. ${ }^{8}$ Sengketa lingkungan (environmental disputes) sendiri merupakan "species" dari "genus" sengketa yang bermuatan konflik atau kontroversi di bidang lingkungan secara leksikal diartikan: "Dispute. A conflict or controversy; a confllct of claims or rights; an assertion of a rlght, claim, or demand on oneside, met by contrary claims or allegations on the other" Terminologi "penyelesaian sengketa" rujukan bahasa Inggrisnya pun beragam: "dispute resolution", "conflict management", conflict settlement", "conflict intervention".9

Pada suatu sengketa, termasuk sengketa lingkungan tidak hanya berdurasi "perselisihan para pihak ansih tetapi perselisihan yang diiringi adanya

7Ibid, hlm. 5

8Pasal 1 angka (19), Undang-Undang Nomor 23 Tahun 1997 tentang Pengelolaan Lingkungan Hidup, Jakarta, 1997.

${ }^{9}$ Takdir Rahmadi, Mekanisme Alternatif Penyelesaian Sengketa Lingkungan Hidup, Makalah Penataran Hukum Lingkungan, (Surabaya: Proyek Kerjasama Hukum Indonesia-Belanda, 1996), hlm. 1 
"tuntutan" (claim). Tuntutan adalah atribut primer dari eksistensi suatu sengketa (konflik). Dengan demikian, rumusan Pasal 1 angka 19 UUPLH yang hanya mengartikan sengketa lingkungan sekedar "perselisihan antara dua pihak atau lebih..." tanpa mencantumkan "claim" terasa kurang lengkap dan tidak merepresentasikan secara utuh keberadaan suatu sengketa. Siapakah sesungguhnya para pihak yang berkonflik dalam sengketa lingkungan? Atau, siapakah subyek sengketa lingkungan itu dan apa pula yang disengketakan (objek sengketa lingkungan)?

Membaca keseluruhan naskah yuridis UUPLH, tampaknya tidak satu Pasal pun yang memberikan jawaban "otentik-stipulatif" atas pertanyaan tersebut. Namun, melalui metode penafsiran interpretatie (methode) dapat di tentukan subyek sengketa lingkungan, yakni: "para pihak yang berselisih". Meski disadari bahwa dalam pelaksanaan pembangunan berkelanjutan ("suistalnable development") yang paling penting adalah: "how to prevent dispute, not how to settle dispute" sesuai dengan adagium: "prevention Is better than cure", dan pepatah yang tidak tersangkal kebenarannya: "an ounce of prevention is worth a pound of cure".

Namun, bukan berarti hukum (UUPLH) harus mengesampingkan sengketa lingkungan tanpa penyelesaian. Sebagai kenyataan yang senantiasa terjadi dan menggejala, sengketa lingkungan membutuhkan penyelesaian yuridis untuk melindungi kepentingan korban pencemaran-perusakan lingkungan sekaligus menyelamatkan lingkungan melalui pendekatan hukum. Konsekuensi suatu negara hukum adalah menempatkan hukum di atas segala kehidupan bernegara dan bermasyarakat. Negara dan masyarakat diatur dan diperintah oleh hukum, bukan diperintah oleh manusia. Hukum berada di atas segalasegalanya, kekuasaan dan penguasa tunduk kepada hukum. Salah satu unsur negara hukum adalah berfungsinya kekuasaan kehakiman yang merdeka yang dilakukan oleh badan peradilan. Pemberian kewenangan yang merdeka tersebut merupakan "katup penekan" (pressure valve), atas setiap pelanggaran hukum tanpa kecuali. Pemberian kewenangan ini dengan sendirinya menempatkan kedudukan badan peradilan sebagai benteng terakhir (the last resort) dalam upaya penegakan "kebenaran" dan "keadilan". 
Pada hal ini tidak ada badan lain yang berkedudukan sebagai tempat mencari penegakan kebenaran dan keadilan (to enforce the truth and justice) apabila timbul sengketa atau pelanggaran hukum. Dalam perkembangan sejarah perlindungan hukum di Indonesia, khusus mengenai perlindungan hukum melalui gugatan perwakilan (class actions) dan hak gugat organisasi (legal standing/ius standi) sedang hangat-hangatnya dibicarakan baik dalam kalangan akademi, maupun di kalangan penasehat hukum, lembaga swadaya masyarakat dan di kalangan badan peradilan sendiri.

Oleh karena baru mengenal konsep gugatan perwakilan (class actions), maka masih banyak kalangan praktisi hukum memberikan pengertian gugatan perwakilan (class actions) identik atau sama dengan pengertian hak gugat organisasi (legal standing/ius standi) pada hal pengertian gugatan perwakilan (class actions) berbeda dengan pengertian gugatan organisasi (legal standing). Perbedaan yang prinsipil antara gugatan perwakilan (class actions) dengan hak gugat organisasi (legal standing) antara lain: dalam gugatan perwakilan (class actions) adalah :

1. Seluruh anggota kelas (class representatives dan class members) sama-sama langsung mengalami atau menderita suatu kerugian.

2. Tuntutannya dapat berupa ganti kerugian berupa uang (monetary damage) dan/atau tuntutan pencegahan (remedy) atau tuntutan berupa perintah pengadilan untuk melakukan atau tidak melakukan sesuatu (injunction) yang sifatnya deklaratif. 10

Sedangkan dalam hak gugatan organisasi (legal standing), adalah :

1. Oganisasi tersebut tidak mengalami kerugian langsung, kerugian dalam konteks gugatan organisasi (legal standing) lebih dilandasi suatu pengertian kerugian yang bersifat publik.

2. Tuntutan organisasi (legal standing) tidak dapat berupa ganti kerugian berupa uang, kecuali ganti kerugian yang telah dikeluarkan organisasi untuk penanggulangannya objek yang dipermasalahkannya dan tuntutannya hanya berupa permintaan pemulihan (remedy) atau tuntutan berupa perintah

10 Ibid, hlm. 5 
pengadilan untuk melakukan atau tidak melakukan sesuatu (injunction) yang bersifat deklaratif11

Secara materiel hukum nasional telah mengatur gugatan perwakilan (class actions) dan hak gugat organisasi (legal standing/ius standi), namun hukum acara yang ditunjuk sebagai hukum formil yang mempertahankan hukum materieal tersebut belum diatur.

Penyelesaian sengketa lingkungan hidup di luar pengadilan, yaitu :

1. Sengketa Lingkungan Hidup :

a. Subyek Sengketa : Pencemar/Perusak $\quad><$ Korban Pencemaran/Perusakan;

b. Obyek Sengketa: Pencemaran Perusakan Aktual, dan Pencemaran Perusakan Potensial,

2. Prinsip-prinsip penyelesaian sengketa lingkungan hidup

a. Para pihak secara suka rela bersedia dan berkeinginan menyelesaikan sengketa secara bermusyawarah.

b. Pihak ke tiga yang bertindak sebagai fasilitator/ mediator/arbiter disetujui oleh para pihak dan harus netral

c. Masing-masing pihak tidak bertahan pada posisinya.

d. Para pihak tidak mempunyai kecurigaan yang berlebihan

e. Persyaratan atau bentuk tuntutan harus rasional

3. Kapan penyelesaian sengketa lingkungan hidup

a. Hakim memberikan perintah untuk mengadakan negosiasi atau mediasi

b. Masyarakat mengajukan tuntutan ganti kerugian atau tindakan tertentu

c. Pemerintah menjatuhkan sanksi administrasi berupa tindakan penyelamatan, penanggulangan, memulihan dan tindakan tertentu lainnya.

d. Penanggung jawab kegiatan keberatan atas ganti rugi atau tindakan tertentu yang harus dilakukan.

e. Para pihak sepakat untuk menyelesaikan sendiri

4. Penyelesaian sengketa lingkungan hidup :

11 Ibid, hlm. 6 
Dapat ditempuh melalui pengadilan atau di luar pengadilan berdasarkan pilihan secara sukarela para pihak yang bersengketa. ${ }^{12}$

Tujuanya adalah melindungi hak keperdataan para pihak yang bersengketa dengan cara cepat dan efisien dengan sasaran :

1. Pencemaran dan kerusakan lingkungan dapat dihentikan

2. Ganti kerugian dapat diberikan

3. Penanggung jawab usaha/kegiatan menaati peraturan perundangan di bidang LH

4. Pemulihan lingkungan dapat dilaksanakan

Penyelesaian sengketa di luar pengadilan : (extrajudicial settlement of dispute-alternative dispute resolution, ADR) Pasal 31 Undang-Undang Pengelolaan Lingkungan Hidup menyebutkan penyelesaian sengketa lingkungan hidup di luar pengadilan, diselenggarakan untuk mencapai kesepakatan bentuk dan besarnya ganti rugi, dan/atau tindakan tertentu, guna Menjamin tidak akan terjadinya atau terulangnya dampak negatif terhadap lingkungan hidup.

Penyelesaian sengketa di Luar pengadilan: (extrajudiciall settlement of dispute - alternative dispute resolution, ADR) Pasal 31 Undang-Undang Pengelolaan Lingkungan Hidup, menyebutkan Penyelesaian sengketa Lingkungan Hidup di luar pengadilan, diselenggarakan untuk mencapai kesepakatan bentuk dan besarnya ganti rugi, dan/atau Tindakan tertentu, guna Menjamin tidak akan terjadinya atau terulangnya dampak negatif terhadap lingkungan hidup.

Respons atas ketidakpuasan (dissatisfaction) penyelesaian sengketa lingkungan melalui "proses litigasi" yang "konfrontatif" dan "zwaarwichtig" (njelimet) adalah "extrajudicial settlement of disputes" atau populer disebut "alternativedispute resolution" (ADR), yaitu penyelesaian konflik lingkungan secara komprehensif di luar pengadilan. ADR merupakan pengertian konseptual yang mengaksentuasikan mekanisme penyelesaian sengketa lingkungan melalui: "negotiation", "conciliation", "mediation", "fact finding", dan "arbitration".

Terdapat juga bentuk-bentuk kombinasi yang dalam kepustakaan dinamakan "hybrid" semisal mediasi dengan arbitrasi yang disingkat "med-arb".

${ }^{12}$ Kementerian Lingkungan Hidup, Peraturan Perundang-Undangan Jilid 1 (Jakarta: Cilunga, 2008), hlm. 9. 
Penyelesaian sengketa lingkungan alternatif ini menurut UUPLH dinamakan "penyelesaian sengketa lingkungan hidup di luar pengadilan". Berdasarkan Pasal 31 Undang-Undang Pengelolaan Lingkungan Hidup, penyelesaian sengketa lingkungan di luar pengadilan diselenggarakan untuk mencapai kesepakatan mengenai bentuk dan besarnya ganti rugi dan/atau tindakan tertentu guna menjamin tidak akan terjadinya atau terulangnya dampak negatif terhadap lingkungan.

Pola penyelesaian sengketa lingkungan dalam ketentuan UndangUndang Pengelolaan Lingkungan Hidup tersebut tampak sebagai koreksi atas kekeliruan sistem Tim Tripihak menurut Undang-undang Nomor 4 Tahun 1982 tentang Ketentuan-ketentuan Pokok Pengelolaan Lingkungan Hidup (UULH\} yang dirasa tidak sesuai dengan ketentuan hukum lingkungan yang dikenal di negara maju seperti: Jepang, Amerika Serikat dan Kanada, yaitu ADR. Namun sayangnya, penyelesaian "model" UULH nampaknya masih melekat dalam Penjelasan Pasal 31 Undang-Undang Pengelolaan Lingkungan Hidup. Para pihak yang berkepentingan meliputi : korban, pelaku dan instansi pemerintah terkait yang populer disebut "Tim Tripihakala". ${ }^{13}$

UULH, justru oleh UUPLH ditambah lagi dengan melibatkan pihak yang mempunyai kepedulian terhadap lingkungan (OLH). Bukankah ini telah memodifikasi Tim Tripihak menjadi "Catur Pihak? Efektifkah? Kita tunggu perkembangannya. Bertumpu pada Pasal 85 UUPPLH, penyelesaian sengketa lingkungan di luar pengadilan sebagaimana dimaksudkan dalam Pasal 84 UUPPLH dapat digunakan jasa pihak ketiga, baik yang tidak memiliki kewenangan mengambil, keputusan maupun yang memiliki kewenangan mengambil keputusan untuk membantu menyelesaikan sengketa lingkungan.

Penyelesaian sengketa lingkungan diluar pengadilan berdasarkan UUPPLH tidaklah dipersyaratkan mempergunakan "santunan", jasa pihak ketiga netral, baik yang "tidak memiliki kewenangan mengambil keputusan" (konsiliasi atau mediasi) maupun melalui "pihak ketiga netral yang memiliki kewenangan mengambil keputusan" (arbitrasi), tetapi boleh dilakukan sendiri oleh para pihak yang bersengketa (negosiasi). Penggunaan jasa pihak ketiga netral 2008), hlm. 6.

13 Siti Sundari, Reformasi Bidang Hukum Lingkungan (Jakarta: Suara Pembaharuan, 
dalam penyelesaian sengketa lingkungan sebatas yang dikehendaki para pihak dan tergantung pada kebutuhan kasus perkasus. Di negara-negara maju, ternyata mengutamakan sarana hukum mediasi sebagai upaya penyelesaian sengketa lingkungan yang efektif.

Hal ini wajar, mengingat mediasi memiliki keunggulan-keunggulan komperatif apabila dibandingkan dengan penyelesaian sengketa secara arbitrasi dan litigasi. Apakah di Indonesia mediasi akan menjadi wahana penyelesaian sengketa lingkungan yang efektif dan efisien dibandingkan dengan arbitrasi maupun litigasi. Penyelesaian sengketa lingkungan hidup di luar pengadilan merupakan pilihan para pihak dan bersifat sukarela. Para pihak juga bebas untuk menentukan lembaga penyedia jasa yang membantu penyelesaian sengketa lingkungan hidup. Lembaga penyedia jasa menyediakan pelayanan jasa penyelesaian sengketa lingkungan hidup dengan menggunakan bantuan arbiter atau mediator atau pihak ketiga lainnya.

Apabila para pihak telah memilih upaya penyelesaian sengketa lingkungan hidup di luar pengadilan, gugatan melalui pengadilan hanya dapat ditempuh apabila upaya tersebut dinyatakan tidak berhasil secara tertulis oleh salah satu atau para pihak yang bersengketa atau salah satu atau para pihak yang bersengketa menarik diri dari perundingan.

Penyelesaian sengketa lingkungan hidup di luar pengadilan diselenggarakan untuk mencapai kesepakatan mengenai bentuk dan besarnya ganti rugi dan/atau mengenai tindakan tertentu guna menjamin tidak akan terjadinya atau terulangnya dampak negatif terhadap lingkungan hidup. Dalam penyelesaian sengketa lingkungan hidup di luar pengadilan dapat digunakan jasa pihak ketiga, baik yang tidak memiliki kewenangan mengambil keputusan maupun yang memiliki kewenangan mengambil keputusan, untuk membantu menyelesaikan sengketa lingkungan hidup.

Dalam rangka menyelesaikan sengketa lingkungan hidup di luar pengadilan, maka mekanismenya menggunakan Alternatif Penyelesaian Sengketa sebagaimana diatur dalam Undang-undang Nomor 30 Tahun 1999 tentang Arbitrase dan Alternatif Penyelesaian Sengketa. Alternatif Penyelesaian Sengketa adalah lembaga penyelesaian sengketa atau beda pendapat melalui 
prosedur yang disepakati para pihak, yakni penyelesaian di luar pengadilan dengan cara konsultasi, negosiasi, mediasi, konsiliasi, atau penilaian ahli.

Mekanisme penyelesaian sengketa dilakukan dengan langkah-langkah sebagai berikut:

a. Sengketa atau beda pendapat perdata dapat diselesaikan oleh para pihak melalui alternatif penyelesaian sengketa yang didasarkan pada itikad baik dengan mengesampingkan penyelesaian secara litigasi di Pengadilan Negeri.

b. Penyelesaian sengketa atau beda pendapat melalui alternatif penyelesaian sengketa sebagaimana dimaksud di atas diselesaikan dalam pertemuan langsung oleh para pihak dalam waktu paling lama 14 (empat belas) hari dan hasilnya dituangkan dalam suatu kesepakatan tertulis.

c. Dalam hal sengketa atau beda pendapat sebagaimana dimaksud di atas tidak dapat diselesaikan, maka atas kesepakatan tertulis para pihak, sengketa atau beda pendapat diselesaikan melalui bantuan seorang atau lebih penasehat ahli maupun melalui seorang mediator.

d. Apabila para pihak tersebut dalam waktu paling lama 14 (empat belas) hari dengan bantuan seorang atau lebih penasehat ahli maupun melalui seorang mediator tidak berhasil mencapai kata sepakat, atau mediator tidak berhasil mempertemukan kedua belah pihak, maka para pihak dapat menghubungi sebuah lembaga arbitrase atau lembaga alternatif penyelesaian sengketa untuk menunjuk seorang mediator.

e. Setelah penunjukan mediator oleh lembaga arbitrase atau lembaga alternatif penyelesaian sengketa, dalam waktu paling lama 7 (tujuh) hari usaha mediasi harus sudah dapat dimulai.

f. Usaha penyelesaian sengketa atau beda pendapat melalui mediator dengan memegang teguh kerahasiaan, dalam waktu paling lama $30 \quad$ (tiga puluh ) hari harus tercapai kesepakatan dalam bentuk tertulis yang ditandatangani oleh semua pihak yang terkait.

g. Kesepakatan penyelesaian sengketa atau beda pendapat secara tertulis adalah final dan mengikat para pihak untuk dilaksanakan dengan itikad baik serta wajib didaftarkan di Pengadilan Negeri dalam waktu paling lama 30 (tiga puluh) hari sejak penandatanganan. 
h. Kesepakatan penyelesaian sengketa atau beda pendapat wajib selesai dilaksanakan dalam waktu paling lama 30 ( tiga puluh) hari sejak pendaftaran.

i. Apabila usaha perdamaian tersebut tidak dapat dicapai, maka para pihak berdasarkan kesepakatan secara tertulis dapat mengajukan usaha penyelesaiannya melalui lembaga arbitrase atau arbitrase ad-hoc.

\section{Hambatan Penyelesaian Sengketa Lingkungan di Luar Pengadilan}

Di dalam Pasal 85 UU Nomor 32 Tahun 2009, penyelesaian sengketa lingkungan dapat dilakukan melalui jasa mediator dan atau arbiter. Sementara di dalam Pasal 86 dijelaskan bahwa penyedia jasa dapat dibentuk oleh masyarakat yang difasilitasi oleh pemerintah yang bersifat bebas dan tidak memihak, baik oleh pemerintah dan/atau masyarakat. Salah satu contoh media yang berkembang dalam penyelesaian sengketa lingkungan di luar pengadilan adalah melalui media Alternative Disputes Resolution yang meliputi proses ligitasi, negosiasi, mediasi, konsolidasi, pencarian Fakta, dan arbitrase.

Sebagai perkembangan hukum lingkungan dipergunakan "Asas Stric Liability" dan "Asas Pembuktian Terbalik" dalam penegakan hukum lingkungan dimana pelaku pencemaran/perusakan lingkungan bertanggung jawab terhadap perbuatannya seketika pada saat terjadinya pencemaran/ perusakan lingkungan tanpa harus dibuktikan terlebih dahulu adanya unsur "kesalahan". Selain itu beban pembuktian diletakkan pada pelaku pencemaran/perusakan lingkungan (tergugat), ia wajib membuktikan bahwa dia tidak dapat dipersalahkan atas kerugian yang terjadi. Kesalahan dianggap ada kecuali tergugat dapat membuktikan sebaliknya.

Di dalam penegakan hukum lingkungan terutama dalam upaya mengajukan ganti kerugian terhadap pencemaran lingkungan masih ditemukan beberapa kendala yang cukup menghambat, antara lain :

1. Walaupun telah banyak peraturan-peraturan yang dikeluarkan pemerintah dalam pengelolaan lingkungan hidup tapi dalam pelaksanaannya masih banyak mengalami hambatan-hambatan untuk mencapai prinsip-prinsip penyelesaian sengketa, terutama menyangkut nominal dan bentuk ganti rugi. 
Dari sekian banyak peraturan, belum terlihat secara jelas kriteria, tata cara perhitungan ganti rugi secara komprehensif dan aspiratif, untuk menghindari silang pendapat/perbedaan pandangan para pihak, maka diperlukan kajian ilmiah dan teknologi serta pendapat para ahli, untuk meyakinkan para pihak tentang keadaan sebenarnya, sehingga para pihak dapat memahami dan tidak bertahan pada posisinya, tidak ada rasa curiga dan mengajukan tuntutan yang rasional untuk musyawarah agar dapat kata sepakat.

2. Sulitnya penegakan hukum administrasi dalam rangka pengelolaan lingkungan, apabila dihadapkan dengan keputusan administratif berupa pencabutan izin usaha yang akan berdampak secara sosiologis ekonomis, dapa menimbulkan desakan dari masyarakat/Lembaga Swadaya Masyarakat (LSM) untuk mengajukan kasus pencemaran dan perusakan ke sidang pengadilan.Hal yang paling sulit untuk membawa kasus-kasus lingkungan ke pengadilan adalah masalah pembuktian dan kesaksian. Pembuktian dimaksudkan untuk membuktikan secara yuridis tentang telah terjadinya tindak pidana lingkungan, sebagaimana diatur dalam pasal 183 sampai dengan pasal 189 KUHAP. Dalam pembuktian tindak pidana lingkungan, digunakan pendekatan masalah lingkungan yang bersifat komprehensif, untuk itu dituntut kemampuan untuk menterjemahkan fakta menurut ilmu pengetahuan (science evidence) menjadi fakta hukum (legal evidence). Karena itu pembuktian tindak pidana lingkungan, didominasi oleh keterangan ahli dan hasil analisis laboratoris, yang harus didukung oleh alat bukti lain. Permasalahan akan timbul apabila Hakim meragukan hasil analisis laboratoris atas sampel dari unsur lingkungan yang tercemar, dengan demikian maka hakim akan memerintahkan penelitian ulang yang kemungkinan hasilnya akan dapat berbeda. Perbedaan tersebut dapat terjadi, antara lain karena : Faktor alam, sungai yang tercemar kemudian tertimpa air hujan dapat menyebabkan pertambahan debit air tersebut menetralizir zatzat pollutan, setidak-tidaknya menurunkan tingkat intensitasnya, sehingga hasilnya sungai tersebut tidak tercemar lagi tetapi hanya terkontaminasi dan masih dalam batas-batas yang dapat ditoleransi. Perbedaan sarana seperti laboratorium, juga dapat mengeluarkan hasil yang berbeda. Diperlukan 
suatu kebijakan mengenai pembakuan atau standar yang mempunyai nilai juridis dalam penetapan mengenai tatacara atau teknik-teknik pengambilan sampel, penunjukan laboratorium dan lain-lain.

3. Masih belum optimalnya peran Badan Lingkungan Hidup sebagai institusi pengendalian dampak lingkungan, karena peran tersebut secara hukum masih melekat pada instansi-instansi sektoral karena belum adanya kewenangan secara penuh untuk melakukan pengawasan dan memerintahkan untuk melaksanakan audit lingkungan apabila diduga suatu kegiatan atau usaha melakukan penyimpangan dalam pengelolaan lingkungan.

4. Di dalam musyawarah penyelesaian sengketa yang menjadi hambatan adalah perbedaan pandangan antara pencemar dan penuntut, dimana pihak pencemar berpandangan berdasarkan aturan dan prosedur sementara masyarakat atau penuntut mengenyampingkan hal tersebut, melainkan berdasarkan kehendak dan kebiasaan di dalam masyarakat sehingga nilai tuntutan dan kesanggupan sangat jauh perbedaannya

\section{E. Kesimpulan}

Penyelesaian sengketa Lingkungan Hidup secara non litigasi dapat dilakukan dengan mekanismenya menggunakan Alternatif Penyelesaian Sengketa sebagaimana diatur dalam Undang-Undang Nomor 30 Tahun 1999 tentang Arbitrase dan Alternatif Penyelesaian Sengketa. Alternatif penyelesaian sengketa di luar pengadilan dengan cara konsultasi, negosiasi, mediasi, konsiliasi, atau penilaian ahli.

Penyelesaian sengketa lingkungan di luar pengadilan masih banyak mengalami hambatan-hambatan untuk mencapai prinsip-prinsip penyelesaian sengketa, terutama menyangkut nominal dan bentuk ganti rugi. Di dalam proses musyawarah penyelesaian sengketa, yang menjadi hambatan adalah perbedaan pandangan antara pencemar dan penuntut dimana pihak pencemar berpandangan berdasarkan aturan dan prosedur sedangkan masyarakat atau penuntut mengenyampingkan hal tersebut, melainkan berdasarkan kehendak dan kebiasaan di dalam masyarakat sehingga nilai tuntutan dan kesanggupan sangat jauh perbedaannya. Hambatan lainnya adalah sulitnya penegakan hukum 
administratif dalam rangka pengelolaan lingkungan aabila dihadapkan dengan keputusan administratif berupa pencabutan izin usaha yang akan berdampak secara sosiologis ekonomis.

\section{Daftar Pustaka}

Abdurrahman, 1998, Pengantar Hukum Lingkungan Indonesia, Alumni, Bandung.

Kementerian Lingkungan Hidup, 1997, Tentang Peraturan Perundang Undangan, Jakarta.

Kementerian Lingkungan Hidup, 2008, Peraturan Perundang-Undangan Jilid 1, Jakarta.

Nurd'a dan Sudharsono, 1991, Aspek Hukum, Satya Wacana, Semarang.

TakdirRahmadi, 1996, Mekanisme Alternatif Penyelesaian Sengketa Lingkungan Hidup, Makalah Penataran Hukum Lingkungan, Proyek Kerjasama Hukum Indonesia-Belanda, Surabaya.

Siti Sundari, 1999, Reformasi Bidang Hukum Lingkungan, Suara Pembaharuan, Jakarta

Soejono Soekanto, 1986, Pengantar Penelitian Hukum, UI Press, Jakarta.

Subagyo, 2008, Hukum Lingkungan, Rineka Cipta, Jakarta.

\section{Peraturan Perundang-Undangan}

Undang-Undang Nomor 23 Tahun 1997 Tentang Pengelolaan Lingkungan Hidup, Jakarta, 2003.

Undang-Undang Nomor Tahun 1999 tentang Arbitrase dan Alternatif Penyelesaian Lingkungan

Undang-Undang Nomor 32 Tahun 2009 Tentang Perlindungan dan Pengelolaan Lingkungan Hidup.

PP Nomor 27 Tahun 1999, Tentang Analisis Dampak Lingkungan Hidup, kementerian Negara Lingkungan Hidup , Jakarta. 